\title{
Dietary incorporation of Sweet Potato Ipomoea batatas shoots improved growth performance and haematological profile of Tilapia Oreochromis niloticus in Hapa Nets
}

\author{
Francis Nuestro BALETA ${ }^{1}$, Patricia MAGISTRADO-CANDELARIA ${ }^{2}$, Diomerl Edward Bondad BALDO ${ }^{3}$, \\ Love Joy PALLAYA-BALETA ${ }^{4}$, Lander Cezar PLANTADO ${ }^{2}$, Mylene Concina NAVARRO ${ }^{2}$
}

Cite this article as:

Baleta, F.N., Magistrado-Candelaria, P., Baldo, D.E.B., Pallaya-Baleta, L.J., Plantado, L.C., Navarro, M.C. (2022). Dietary incorporation of Sweet Potato Ipomoea batatas shots improved growth performance and haematological profile of Tilapia Oreochromis niloticus inHapa Nets.

Aquatic Research, 5(1), 1-10. https://doi.org/10.3153/AR22001

\footnotetext{
${ }^{1}$ National Research Council of the Philippines, DOST Compound, Bicutan, Taguig City, Philippines

2 Partido State University Sagñay Campus, Sagñay, Camarines Sur, Philippines

${ }^{3}$ Partido State University Caramoan Campus, Caramoan, Camarines Sur, Philippines

${ }^{4}$ College of Business Management, Partido State University Goa Campus, Goa, Camarines Sur, Philippines
}

\section{ORCID IDs of the author(s):}

F.N.B. 0000-0002-5266-1893

P.M.C. 0000-0001-6399-9622

D.E.B.B. 0000-0001-7122-5301

L.J.P.B. 0000-0003-2701-9687

L.C.P. 0000-0002-1697-2272

M.C.N. 0000-0002-9450-1126

Submitted: 14.03 .2021

Revision requested: 08.05 .2021

Last revision received: 20.05 .2021

Accepted: 20.05.2021

Published online: 01.11.2021

Correspondence:

Francis Nuestro BALETA

E-mail: fnbaleta19@yahoo.com

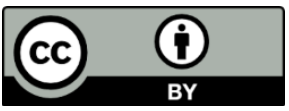

Available online at

http://aquatres.scientificwebjournals.com

\begin{abstract}
This study was conducted to evaluate the potential of sweet potato Ipomoea batatas powder (IbSPP), hot-water extracts (IbSPHWE) and crude ethanolic extracts (IbSPCEE) as growth promoter and immunoenhancer for tilapia cultured in hapa nets. Fish were divided randomly into four Treatments: T1 (control group) was fed a practical diet (PD) while T2, T3 and T4 were fed PD + IbSP powder (P), PD + IbSP hot-water extract (HWE), PD + IbSP Crude Ethanol Extracts (CCE), respectively. The growth indices and haematological profile of cultured fish were recorded after four months of feeding experiment.

The final weight, weight gain, specific growth rate, condition factor, FCR, PER, FER were significantly higher in fishes that received PD +IbSPHWE than those that received either PD, PD + IbSPCEE or PD+ IbSPP only. The same trend was observed with the RBC, Hb, HCT, WBC and the PLT and its indices. The study has demonstrated that incorporation of the hot-water extracts of $I$. batatas could improve the growth performance and increase immunocompetence of $O$. niloticus as evidenced by improved haematological profile.
\end{abstract}

Keywords: Oreochromis niloticus, Ipomoea batatas, Immunostimulants, Hot-Water extracts, Haematological profile 


\section{Introduction}

The production of commercially-important aquaculture species significantly increased during the past decades. To meet the market demands, fish culture practices in enclosed spaces like ponds, net cages and tanks had intensified. Along with intensive fish culture are increase in stocking density, water quality and environment manipulation, enhanced fish nutrition and feeding management and fish health management. However, with increased stocking density, fish are exposed to a number of stressors such as overcrowding, transport, handling, which adversely affect the health status of cultured fish. Improvement of the health status and growth performance of cultured fish is of great importance to aquaculture. Strengthening the defense mechanism of fish through prophylactic administration of immunostimulants seem to be one of the most promising method of controlling diseases in aquaculture (Li et al, 2004; Robertsen, 1999; Raa et al, 1992). These substances increase the immunocompetence and resistance to pathogens and diseases by enhancing both the specific and non-specific defense mechanisms of fish and other organisms (Zhou et al, 2003).

Recently, increasing attention is being paid to the use of plant products for disease control in aquaculture as an alternative to chemical treatments (Reverter et al, 2014) Numerous studies documented the efficacy of plant extracts as anti-stress, growth promoter, appetite stimulator, immunobooster, and elicit disease resistance and anti-pathogen properties in fish and shrimp aquaculture due to the presence of active principles like alkaloids, terpenoids, tannins, saponins, glycosides, flavonoids, phenolics, steroids or essential oils (Chakraborty and Hancz, 2011; Citarasu, 2010).

The sweet potato Ipomoea batatas $(\mathrm{L})$ is a dicotyledonous plant that belongs to the bindweed or morning-glory family Convolvulaceae. In the Philippines, sweet potatoes (locally known as camote or kamote) are an important food crop in rural areas. They are often a staple among impoverished families in provinces, as they are easier to cultivate and cost less than rice, it can even be found growing along the backyards of some houses in the rural areas of the country. The young shoots (red or purple in color) and leaves of I. batatas are sometimes eaten as a salad or a main ingredient in some stew. The leaves are even used as a cheap source of protein for ruminant feeds.

Various leaf meal and other plant extracts have been studied as a potential feed ingredient for fish and shrimp (Garg et al, 2019; Labh et al, 2017; Wu et al, 2016; Ganzon-Naret, 2014; Baleta et al, 2013; Kaleeswaran et al, 2011; Abd El-Hakim et al, 2010;
Olmendo Sanchez et al, 2009; Afuang et al, 2003; ), however, utilization of sweet potato leaf meal and extracts as a feed ingredient for animal and fish diets is scarce (Adewolu, 2008; Abonyi et al, 2012). The study was conducted to determine the effects of sweet potato shoots as growth promoter and immunobooster for tilapia particularly on the survival, growth indices and haematological profile.

\section{Material and Methods}

\section{Experimental Fish}

Healthy tilapia (O. niloticus) with a mean weight of 17-18 g were obtained from the Partido State University (PSU) Multispecies Hatchery Laboratory, PSU Sagñay Campus. Fish were acclimated for two weeks at the experimental hapa nets $(3 \mathrm{~m} \mathrm{x}$ $5 \mathrm{~m} \times 1 \mathrm{~m}$ ) installed in $1000 \mathrm{~m}^{2}$ pond. Fish were fed with commercial feed ad libitum twice per day until initiation of the experiment. During the feeding experiment, ten (10) fish were stocked at each hapa net $(1 \mathrm{~m} \times 1 \mathrm{~m} \times 1 \mathrm{~m})$ Water parameters were measured during the conditioning phase and the duration of the feeding experiment. The water temperature, $\mathrm{pH}$ and dissolved oxygen ranged between $29 \pm 2.2^{\circ} \mathrm{C}, 7.2-7.5 \mathrm{pH}$ and $6.4 \pm 1.3 \mathrm{mg}$ $\mathrm{L}^{-1}$, respectively during the culture period.

\section{Collection and Preparation of I. batatas Powdered Leaves}

The shoots of I. batatas were purchased at the local market of the town. Preparation of the feeds were done at the CAS Science Laboratory, Partido State University, Goa, Camarines Sur, Philippines. The leaves were washed thoroughly with tap water and the unwanted parts (stems and the necrotic parts of the leaves) were removed. The cleaned and sorted leaves were airdried for two weeks at room temperature. The air-dried leaves were oven-dried at $60^{\circ} \mathrm{C}$ until a brittle and crispy consistency of the leaves is achieved. The dried leaves were crushed and grinded with a blender and hammer mill until powdered particles are produced. The powdered leaves were stored in an airtight plastic container at room temperature until use. The ratio of wet to dried powdered I. batatas leaves were recorded.

\section{Preparation of the Hot-Water Extracts of I. batatas}

The hot-water extract of Ipomea batatas shoots were prepared based on the method described by Fujiki et al. (1992), Hou and Chen (2005) and Baleta et al (2013) with modifications. Briefly, $100 \mathrm{~g}$ of dried I. batatas powder were added to 1000 $\mathrm{mL}$ of distilled water and were boiled for $3 \mathrm{~h}$ in a water bath set-up. The boiled suspension was passed through a nylon mesh 
and the filtrate were frozen until use. The frozen I. batatas HWE were thawed and were boiled before use for the experiment.

\section{Preparation of the I. batatas Crude Ethanolic Extracts}

Five hundred grams of I. batatas powder were soaked in $5 \mathrm{~L}$ of $95 \%$ ethanol and incubated in the dark condition at room temperature for $72 \mathrm{hrs}$. Thereafter, the supernatant was filtered using Whatman No. 42 filter paper. The supernatant was then evaporated to dry under reduced condition $\left(40^{\circ} \mathrm{C}\right)$ via a rotary evaporator (IKA-100). The obtained extract was stored at a refrigerator.

\section{Preparation of Experimental Diets and Feeding Experiment}

Fish were divided randomly into four Treatments (T1, T2, T3 and T4). Each group was divided into two subgroups (A and B; each sub-group had triplicate of 30 fish). Subgroup A was used for growth and survival studies while subgroup B was used for examination of haematological profile. T1 (control group) was fed a practical diet. Experimental diets were formulated from locally available ingredients to satisfy the nutrient requirements of $O$. niloticus (Table 1). The proximate composition of the practical and experimental diets is presented in Table 2 The ingredients were ground, mixed, pelletized to a $1.5 \mathrm{~mm}$ diameter and dried at room temperature for a day. Pellets were stored at $4^{\circ} \mathrm{C}$ until use. T2 was fed practical diet supplemented with $5 \%$ I. batatas powder $\left(50 \mathrm{~g} \mathrm{~kg}^{-1}\right)$. $\mathrm{T} 3$ and $\mathrm{T} 4$ were given with practical diet supplemented with $5 \%$ I. batatas $\operatorname{HWE}\left(50 \mathrm{~mL} \mathrm{~kg}^{-1}\right)$ and $5 \%$ I. batatas CEE $\left(50 \mathrm{~g} \mathrm{~kg}^{-1}\right)$, respectively . Food was provided twice daily (8:00 am and 4:00 pm) at the rate of 5\% of fish live body weight. The amount of food was readjusted every two weeks according to fish weight.

Table 1. Ingredients (per kg) for the experimental diets of tilapia

\begin{tabular}{lcccc}
\hline \hline & & \multicolumn{2}{c}{ Experimental Groups } \\
Feed Ingredient & Practical Diet (PD) & PD + IbSP P & PD + IbSP HWE & PD + IbSP CEE \\
\hline Fish Meal (local) & 0.25 & 0.28 & 0.28 & 0.28 \\
Corn Meal & 0.12 & 0.10 & 0.10 & 0.10 \\
Soy bean meal & 0.28 & 0.27 & 0.27 & 0.27 \\
Rice bran & 0.21 & 0.16 & 0.16 & 0.16 \\
Corn Oil & 0.05 & 0.05 & 0.05 & 0.05 \\
Vit. And Minerals & 0.04 & 0.04 & 0.04 & 0.04 \\
Corn Starch & 0.05 & 0.05 & 0.05 & 0.05 \\
IbSP Powder & & 0.05 & & \\
IbSP HWE & & & 0.05 & 0.05 \\
IbSP CCE & & & & \\
\hline \hline
\end{tabular}

Note: IbSP - Ipomoea batatas Sweet Potato Powder;

IbSP HWE - Ipomoea batatas Sweet Potato Hot-water Extract;

IbSP CCE - Ipomoea batatas Sweet Potato Crude Ethanolic Extract

Table 2. Proximate composition of the practical and experimental diets of tilapia

\begin{tabular}{lcccc}
\hline \hline & & \multicolumn{2}{c}{ Experimental Groups } \\
Feed Ingredient & Practical Diet (PD) & PD + IbSP P & PD + IbSP HWE & PD + IbSP CEE \\
\hline Crude Protein (N x 6.25) & 25.12 & 25.48 & 25.25 & 24.26 \\
Crude Fat & 12.45 & 13.91 & 12.24 & 12.23 \\
Ash & 10.42 & 11.05 & 11.08 & 10.97 \\
Moisture & 12.89 & 12.93 & 12.13 & 13.08 \\
Total Carbohydrates (\%) & 34.15 & 34.63 & 34.20 & 34.94 \\
\hline \hline
\end{tabular}

Note: IbSP - Ipomoea batatas Sweet Potato Powder;

IbSP HWE - Ipomoea batatas Sweet Potato Hot-water Extract;

IbSP CCE - Ipomoea batatas Sweet Potato Crude Ethanolic Extract 


\section{Growth Performance}

The experimental fish in sub-group A were counted and weighed at the end of the feeding experiment to assess growth performance. The final body weight (FBW), weight gain (WG), specific growth rate (SGR), feed conversion ratio (FCR), protein efficiency ratio (PER), feed efficiency ratio (FER) and condition factor (CF) were determined according to De Silva and Anderson (1995), Hevroy et al. (2005) and Jafarian et al. (2007).

\section{Haematological Profile, Blood Collection and Plasma Separation}

Six fish were randomly collected from each treatment in subgroup B at the end of the feeding experiment. Whole blood were collected from the caudal vein of each fish using 1cc syringe (25 g x 5/8). The collected blood was transferred in $0.5 \mathrm{~mL}$ heparin vacutainer tube with EDTA and maintained at low temperature until analyses. The blood parameters red blood cell count (RBC; $10^{6} / \mathrm{mL}$ ), hematocrit (HCT; \%), hemoglobin concentration $(\mathrm{HB} ; \mathrm{g} / \mathrm{l})$, mean corpuscular volume (MCV; fl), mean corpuscular hemoglobin ( $\mathrm{MCH}$; pg) and mean corpuscular hemoglobin concentration (MCHC; g/dl), white blood cell count (WBC; $10^{3} / \mathrm{mL}$ ), lymphocytes (LYMP\#; $10^{6} / \mathrm{mL}$ ), monocytes (Mon\#; 106/mL), eosinophil (Eos\#; 10\% $/ \mathrm{mL}$ ), platelet count (PLT; $10^{6} / \mathrm{mL}$ ), mean platelet volume (MPV; fl), platelet distribution width (PDW; fl), platelet large cell count (P-LCC;
$10^{6} / \mathrm{mL}$ ) and platelet large cell ratio (P-LCR; \%) were analyzed using Rayto Auto Hematological Analyzer (RT-7600).

\section{Statistical Analyses}

All data were analyzed by one-way ANOVA $(\mathrm{P}<0.05)$ and Tukey's tests. A value of $\mathrm{P}<0.05$ was considered statistically significant. All statistical analyses were performed using SPSS v.26 (SPSS, IL, USA).

\section{Results and Discussion}

The final weight, weight gain, specific growth rate and condition factor were significantly higher in fishes that received practical diets supplemented with the HWE of I. batatas than those that received either PD, PD + IbSPCEE or PD+ IbSPP only for four months (Table 3). Similarly, the feed conversion ratio, protein efficiency ratio, and feed efficiency ratio is significantly higher in T3 (PD + IbSPHWE) as compared to T4 (PD + IbSPCEE), T1 (PD), and T2 (PD + IbSPP) after the feeding experiment (Table 4).

Significant increase in RBC, Hb, HCT and other RBC indices were also observed in fishes that received PD+IbSPHWE as compared to fishes that received either PD + IbSPCEE, PD+ IbSPP, or PD only (Table 5) $(\mathrm{P}<0.05)$. The same trend was observed with the WBC and other leukocyte indices (Table 6), and even with the PLT and its indices (Table 7).

Table 3. Growth Performance of $O$. niloticus under different diets with sweet potato $I$. batatas powder and extracts after 16wk culture period

\begin{tabular}{llccc}
\hline \hline Parameters & \multicolumn{3}{c}{ Feeds } \\
\cline { 2 - 4 } & \multicolumn{1}{c}{$\begin{array}{c}\text { Control } \\
\text { Feed 1 } \\
\left(\mathbf{0 ~ g ~ k g - ~}{ }^{-1} \text { IbSP) }\right.\end{array}$} & $\begin{array}{c}\text { Experimental Treatments } \\
\text { (PD + IbSP Powder) }\end{array}$ & $\begin{array}{c}\text { Feed 3 } \\
\text { (PD + IbSHWE) }\end{array}$ & $\begin{array}{c}\text { Feed 4 } \\
\text { (PD + IbSCEE) }\end{array}$ \\
\cline { 2 - 5 } & $9.50 \pm 0.35^{\mathrm{a}}$ & $10.13 \pm 0.12^{\mathrm{a}}$ & $9.23 \pm 0.44^{\mathrm{a}}$ & $9.47 \pm 0.43^{\mathrm{a}}$ \\
\hline Length (Initial) cm & $16.23 \pm 0.40^{\mathrm{b}}$ & $16.11 \pm 0.35^{\mathrm{b}}$ & $18.49 \pm 0.44^{\mathrm{a}}$ & $16.86 \pm 0.33^{\mathrm{b}}$ \\
\hline Length (Final) cm & $14.03 \pm 0.44^{\mathrm{a}}$ & $14.65 \pm 0.23^{\mathrm{a}}$ & $14.23 \pm 0.20^{\mathrm{a}}$ & $14.93 \pm 1.09^{\mathrm{a}}$ \\
\hline Weight (Initial) g & $78.80 \pm 5.69^{\mathrm{b}}$ & $78.67 \pm 4.83^{\mathrm{b}}$ & $120.24 \pm 5.69^{\mathrm{a}}$ & $85.40 \pm 5.42^{\mathrm{b}}$ \\
\hline Weight (Final) g & $60.84 \pm 5.20^{\mathrm{b}}$ & $60.81 \pm 14.23^{\mathrm{b}}$ & $101.25 \pm 4.71^{\mathrm{a}}$ & $67.26 \pm 6.25^{\mathrm{b}}$ \\
\hline Weight gain (g) & $100 \pm 0.00^{\mathrm{a}}$ & $100 \pm 0.00^{\mathrm{a}}$ & $100 \pm 0.00^{\mathrm{a}}$ & $100 \pm 0.00^{\mathrm{a}}$ \\
\hline Survival rate (\%) & $0.57 \pm 0.05^{\mathrm{b}}$ & $0.56 \pm 0.04^{\mathrm{b}}$ & $0.93 \pm 0.05^{\mathrm{a}}$ & $0.62 \pm 0.05^{\mathrm{b}}$ \\
\hline Average Daily weight gain (g) & $0.06 \pm 0.01^{\mathrm{ab}}$ & $0.05 \pm 0.00^{\mathrm{b}}$ & $0.08 \pm 0.01^{\mathrm{a}}$ & $0.06 \pm 0.01^{\mathrm{ab}}$ \\
\hline Average Daily length gain (g) & $0.06 \pm 0.09^{\mathrm{b}}$ & $1.47 \pm 0.05^{\mathrm{b}}$ & $1.87 \pm 0.03^{\mathrm{a}}$ & $1.53 \pm 0.05^{\mathrm{b}}$ \\
\hline Specific Growth rate & $1.51 \pm 0.09^{\mathrm{b}}$ & $1.52 \pm 0.02^{\mathrm{a}}$ & $1.67 \pm 0.04^{\mathrm{a}}$ & $1.54 \pm 0.05^{\mathrm{a}}$ \\
\hline Condition Factor & $1.51 \pm 0.03^{\mathrm{a}}$ & &
\end{tabular}

Means with the same letters as superscripts are not significantly different $(\mathrm{P}>0.05)$

Values are expressed as mean \pm standard error, calculated from the mean-square for error of the ANOVA 
Table 4. Parameters of feed and nutrient utilization of $O$. niloticus under different diets with sweet potato I. batatas powder and extracts after 16-wk culture period

\begin{tabular}{|c|c|c|c|c|}
\hline \multirow[t]{3}{*}{ Parameters } & \multicolumn{4}{|c|}{ Feeds } \\
\hline & \multirow{2}{*}{$\begin{array}{c}\text { Control } \\
\text { Feed } 1 \\
\left(0 \mathrm{~g} \mathrm{kg-}^{-1} \mathrm{IbSP}\right)\end{array}$} & \multicolumn{3}{|c|}{ Experimental Treatments } \\
\hline & & $\begin{array}{c}\text { Feed } 2 \\
(\text { PD }+ \text { IbSP Powder) }\end{array}$ & $\begin{array}{c}\text { Feed 3 } \\
(\text { PD + IbSHWE) }\end{array}$ & $\begin{array}{c}\text { Feed } 4 \\
(\text { PD + IbSCEE) }\end{array}$ \\
\hline Feed intake ( $\mathrm{g}$ feed $\mathrm{g}^{-1}$ fish) & $95.94 \pm 0.08^{\mathrm{b}}$ & $96.52 \pm 0.64^{\mathrm{b}}$ & $98.59 \pm 0.56^{\mathrm{a}}$ & $93.85 \pm 0.76^{\mathrm{c}}$ \\
\hline Feed conversion ratio & $1.51 \pm 0.15^{\mathrm{a}}$ & $1.52 \pm 0.11^{\mathrm{a}}$ & $0.94 \pm 0.04^{b}$ & $1.35 \pm 0.11^{\mathrm{a}}$ \\
\hline Protein Efficiency Ratio & $2.15 \pm 0.20^{b}$ & $2.13 \pm 0.16^{\mathrm{b}}$ & $3.53 \pm 0.18^{\mathrm{a}}$ & $2.34 \pm 0.18^{\mathrm{b}}$ \\
\hline Feed efficiency ratio & $67.52 \pm 6.41^{\mathrm{b}}$ & $66.30 \pm 4.65^{\mathrm{b}}$ & $107.47 \pm 5.05^{\mathrm{a}}$ & $75.12 \pm 5.91^{b}$ \\
\hline
\end{tabular}

Means with the same letters as superscripts are not significantly different $(\mathrm{P}>0.05)$

Values are expressed as mean \pm standard error, calculated from the mean-square for error of the ANOVA

Table 5. Erythrocyte indices of $O$. niloticus under different diets with sweet potato $I$. batatas powder and extracts after 16-wk culture period.

\begin{tabular}{|c|c|c|c|c|c|c|c|}
\hline \multirow[b]{2}{*}{ Treatment } & \multicolumn{7}{|c|}{ Erythrocyte Indices } \\
\hline & $\begin{array}{c}\text { Red Blood } \\
\text { Cell } \\
\text { RBC } \\
\left(10^{6} / \mathbf{m L}\right)\end{array}$ & $\begin{array}{c}\text { Hemoglobin } \\
\text { Hb } \\
\text { (g/dL) }\end{array}$ & $\begin{array}{c}\text { Hematocrit } \\
\text { HCT } \\
(\%)\end{array}$ & $\begin{array}{l}\text { Mean Corpus- } \\
\text { cular Volume } \\
\text { MCV } \\
\text { (fl) }\end{array}$ & $\begin{array}{l}\text { Mean Cor- } \\
\text { puscular He- } \\
\text { moglobin } \\
\text { MCH } \\
\text { (pg) }\end{array}$ & $\begin{array}{c}\text { Mean Corpus- } \\
\text { cular Hemoglo- } \\
\text { bin Concera- } \\
\text { tion } \\
\text { MCHC } \\
(\mathrm{g} / \mathrm{dL}) \\
\end{array}$ & $\begin{array}{c}\text { Red Blood } \\
\text { Cell Distri- } \\
\text { bution } \\
\text { Width } \\
\text { RDW-CV }\end{array}$ \\
\hline $\mathrm{PD}$ & $1.69 \pm 0.03^{c}$ & $78.00 \pm 2.85^{\mathrm{c}}$ & $28.13 \pm 1.09^{\mathrm{c}}$ & $169.01 \pm 3.81^{\mathrm{c}}$ & $49.64 \pm 0.42^{b}$ & $254.33 \pm 8.29^{\mathrm{b}}$ & $10.05 \pm 0.49^{b}$ \\
\hline PD+IbS Powder & $1.72 \pm 0.03^{\mathrm{ac}}$ & $84.87 \pm 1.02^{\mathrm{b}}$ & $29.52 \pm 0.58^{\mathrm{c}}$ & $172.84 \pm 3.66^{b c}$ & $48.05 \pm 0.83^{b}$ & $269.67 \pm 4.42^{\mathrm{b}}$ & $15.75 \pm 1.79^{\mathrm{a}}$ \\
\hline PD+IbS HWE & $2.20 \pm 0.04^{\mathrm{a}}$ & $106.33 \pm 3.09^{\mathrm{a}}$ & $39.68 \pm 1.12^{\mathrm{a}}$ & $185.53 \pm 2.49^{\mathrm{a}}$ & $53.27 \pm 0.94^{\mathrm{a}}$ & $329.53 \pm 10.66^{\mathrm{a}}$ & $20.57 \pm 2.40^{\mathrm{a}}$ \\
\hline PD+IbS CEE & $1.82 \pm 0.03^{b}$ & $88.33 \pm 1.99^{b}$ & $32.26 \pm 0.69^{\mathrm{b}}$ & $181.25 \pm 2.96^{\mathrm{ab}}$ & $49.28 \pm 0.55^{\mathrm{b}}$ & $274.33 \pm 3.75^{\mathrm{b}}$ & $17.06 \pm 1.54^{\mathrm{b}}$ \\
\hline
\end{tabular}

Means with the same letters as superscripts are not significantly different $(\mathrm{P}>0.05)$

Values are expressed as mean \pm standard error, calculated from the mean-square for error of the ANOVA

Table 6. Leukocyte indices of $O$. niloticus under different diets with sweet potato $I$. batatas powder and extracts after 16-wk culture period.

\begin{tabular}{lccccc}
\hline \hline & \multicolumn{5}{c}{ Leukocyte Indices } \\
\cline { 2 - 6 } \multicolumn{1}{c}{ Treatment } & $\begin{array}{c}\text { White Blood } \\
\text { Cell WBC } \\
(\mathbf{1 0} / \mathbf{m L})\end{array}$ & $\begin{array}{c}\text { Lymphocytes } \\
\text { LYMP\# } \\
(\mathbf{1 0} / \mathbf{m L})\end{array}$ & $\begin{array}{c}\text { Monocytes } \\
\text { MON } \\
(\mathbf{1 0} / \mathbf{m L})\end{array}$ & $\begin{array}{c}\text { Nuetrophils } \\
\text { NEUT } \\
(\mathbf{1 0} / \mathbf{m L})\end{array}$ & $\begin{array}{c}\text { Eosinophils } \\
\text { EOS } \\
(\mathbf{1 0} / \mathbf{m L})\end{array}$ \\
\hline $\mathrm{PD}$ & $67.45 \pm 0.84^{\mathrm{c}}$ & $67.02 \pm 1.06^{\mathrm{c}}$ & $67.02 \pm 1.06^{\mathrm{c}}$ & $15.84 \pm 5.77^{\mathrm{a}}$ & $2.34 \pm 1.21^{\mathrm{a}}$ \\
$\mathrm{PD}+\mathrm{IbS} \mathrm{Powder}$ & $78.05 \pm 2.38^{\mathrm{b}}$ & $72.16 \pm 1.92^{\mathrm{b}}$ & $72.16 \pm 1.92^{\mathrm{b}}$ & $16.59 \pm 10.37^{\mathrm{a}}$ & $2.26 \pm 0.62^{\mathrm{a}}$ \\
$\mathrm{PD}+\mathrm{IbS} \mathrm{HWE}$ & $88.75 \pm 1.86^{\mathrm{a}}$ & $82.23 \pm 1.30^{\mathrm{a}}$ & $82.23 \pm 1.30^{\mathrm{a}}$ & $22.48 \pm 5.47^{\mathrm{a}}$ & $1.38 \pm 0.74^{\mathrm{a}}$ \\
$\mathrm{PD}+\mathrm{IbS} \mathrm{CEE}$ & $78.44 \pm 2.09^{\mathrm{b}}$ & $79.28 \pm 1.32^{\mathrm{a}}$ & $79.28 \pm 1.32^{\mathrm{a}}$ & $22.92 \pm 11.42^{\mathrm{a}}$ & $1.51 \pm 1.08^{\mathrm{a}}$ \\
\hline \hline
\end{tabular}

Means with the same letters as superscripts are not significantly different $(\mathrm{P}>0.05)$

Values are expressed as mean \pm standard error, calculated from the mean-square for error of the ANOVA 
Table 7. Platelet indices of $O$. niloticus under different diets with sweet potato I. batatas powder and extracts after 16-wk culture period.

\begin{tabular}{|c|c|c|c|c|c|c|}
\hline \multirow[b]{2}{*}{ Treatment } & \multicolumn{6}{|c|}{ PLT Indices } \\
\hline & $\begin{array}{l}\text { Platelet } \\
\text { PLT } \\
\left(10^{6} / \mathbf{m L}\right)\end{array}$ & $\begin{array}{l}\text { Mean Platelet } \\
\text { Volume } \\
\text { MPV (fl) }\end{array}$ & $\begin{array}{l}\text { Platelet Distribution } \\
\text { Width PDW } \\
\text { (fl) }\end{array}$ & $\begin{array}{l}\text { Plateletcrit } \\
\text { PCT } \\
\text { (\%) }\end{array}$ & $\begin{array}{c}\text { Platelet-Large } \\
\text { Cell Count } \\
\text { P-LCC } \\
\left(10^{6} / \mathbf{m L}\right)\end{array}$ & $\begin{array}{c}\text { Platelet- } \\
\text { Large Cell } \\
\text { Ratio } \\
\text { P-LCR } \\
\text { (\%) }\end{array}$ \\
\hline PD & $321.93 \pm 22.47^{c}$ & $9.85 \pm 2.23^{\mathrm{a}}$ & $4.75 \pm 0.34^{\mathrm{a}}$ & $0.21 \pm 0.03^{b}$ & $6.53 \pm 0.61^{\mathrm{a}}$ & $28.80 \pm 3.72^{\mathrm{a}}$ \\
\hline PD+IbS Powder & $446.27 \pm 26.06^{b}$ & $5.13 \pm 0.07^{b}$ & $4.19 \pm 0.08^{\mathrm{a}}$ & $0.24 \pm 0.01^{\mathrm{b}}$ & $7.11 \pm 0.47^{\mathrm{a}}$ & $34.27 \pm 2.83^{\mathrm{a}}$ \\
\hline PD+IbS HWE & $694.33 \pm 43.45^{\mathrm{a}}$ & $4.91 \pm 0.07^{\mathrm{b}}$ & $4.17 \pm 0.09^{\mathrm{a}}$ & $0.35 \pm 0.03^{\mathrm{a}}$ & $6.17 \pm 0.42^{\mathrm{a}}$ & $37.86 \pm 4.56^{\mathrm{a}}$ \\
\hline PD+IbS CEE & $413.00 \pm 17.68^{b}$ & $5.17 \pm 0.11^{\mathrm{b}}$ & $4.12 \pm 0.09^{\mathrm{a}}$ & $0.28 \pm 0.02^{\mathrm{b}}$ & $7.03 \pm 0.77^{\mathrm{a}}$ & $36.27 \pm 3.96^{\mathrm{a}}$ \\
\hline
\end{tabular}

Means with the same letters as superscripts are not significantly different $(\mathrm{P}>0.05)$

Values are expressed as mean \pm standard error, calculated from the mean-square for error of the ANOVA

Incorporation of feed additives; such as vitamins, minerals and prebiotics are considered as promising options in aquaculture particularly in the enhancement of growth, disease prevention and improvement of aquatic animal health.

Several plant extracts are reported to stimulate appetite and promote weight gain when they are administered to cultured fish (Harikrishnan et al., 2012; Pavaraj et al., 2011; Takaoka et al., 2011). In the study of Shalaby et al. (2006), food intake, specific growth rate and final weight of Nile tilapia (Oreochromis niloticus) increased when garlic was incorporated in the diet. Punitha et al (2008) found out that grouper Ephinephelus tauvina fed diets with a mixture of methanolic herb extracts (Bermuda grass (Cynodon dactylon), Long pepper (Piper longum), stonebreaker (Phyllanthus niruri), coat buttons (Tridax procumbens) and ginger (Zingiber officinalis)) exhibited $41 \%$ increase in weight of grouper than the control group. Aside from gain in weight, several studies demonstrated that plant extracts somehow improve digestibility and availability of nutrients resulting in an increase in feed conversion and leading to a higher protein synthesis (Citarasu, 2010; Nya and Austin, 2009; Talpur et al., 2013). For example, Putra et al. (2013) showed that supplemented diet with $1 \%$ of ethanolic katuk extract (Sauropus androgynous) stimulated appetite, growth and improved food utilization (lower feed conversion ratio) in grouper Ephinephelus coioides. The health status of the fish can also be determined by evaluating the Specific growth rate (SGR) and condition factor (CF). Extracts from plants and other products may control, limit and inhibit the growth and colonization of numerous pathogenic and nonpathogenic species of bacteria in fish guts. The incorporation of these plant extracts in the diets of fish may provide greater efficiency in the feed utilization, which may result in improved growth and feed efficiency (Jain et al, 2008; Bedford, 2000). Our study demonstrated that the incorporation of I. batatas extracts in the practical diets of tilapia significantly improve the gain in weight, specific growth rate, feed conversion ratio, protein efficiency ratio, feed efficiency ratio and condition factor of tilapia.

Haematological profile is a pathophysiological reflector of the entire body and the counts of various parameters in blood give an indication to the health status of fish by determining any abnormality brought about by using these immunostimulants (Tewary and Patra, 2011). The results of the present study indicated that inclusion of I. batatas in the fish diet increased the $\mathrm{RBC}$ counts and the values appeared to increase with increasing dietary inclusion levels of $I$. batatas in healthy fish. The result of the present study is in agreement with observed increase in RBC in: C. carpio fed extract of Eurphobia hirta (Pratheepa and Sukumaran, 2014), and Clarias gariepinus fed Morus alba extract (Sheikhlar et al, 2014). These results also correspond with those by Nya and Austin (2009) who reported the counts of $\mathrm{RBC}$ were significantly higher in rainbow trout fed with the garlic-added and ginger-added diets. The apparent increase in RBC after dietary supplementation with $I$. batatas may be related to presence of iron, vitamin $\mathrm{A}$, vitamin $\mathrm{B}$, vitamin $\mathrm{C}$ and vitamin $\mathrm{B} 12$ which are required for $\mathrm{RBC}$ production (Dugency et al, 2003).

The nutritive status of fish can be linked to the health condition of an animal and potential way they deal with stress resulting from their surrounding environment. In our study, a clear link between increased weight and length gains with the increased number of RBCs and other haematological parameters can be observed. The primary function of WBC's is to defend the body 
against foreign pathogenic organisms. In the current study, the amount of WBC's, neutrophils, RBC's and hemoglobin concentration was greater in treatment 3 (PD+IbSPHWE) which confirms that this increase was the underplaying factor for the enhanced growth of the fish. Also, result of haematological profile of our study denotes that the health status of tilapia was at the optimal level as well as no or minimal infection or pathogenic activity in the fish body.

Hematological parameters are used to provide information about the health and physiological status of fish, feeding conditions and water quality in which they live (Fazio et al., 2013). $\mathrm{WBC}, \mathrm{RBC}, \mathrm{Hct}$, and $\mathrm{Hb}$ values are particularly recommended on a routine basis to monitor the health of the stock in fish farms. In the previous study on the effects of herbal immunostimulants on hematology and the immune system, it has been reported that plants bioactive substances caused an increase in blood cells counts, and this triggered the immune system and enhanced a natural defense in distinct fish species (Nya and Austin, 2009a; Talpur et al., 2013; Ajeel and Faragi, 2013; Haghighi and Rohani, 2013).

\section{Conclusion}

The study demonstrated that incorporation of I. batatas hot-water extract in the practical diets of $O$. niloticus is a potential feed ingredient that significantly improved the growth performance as evidenced by enhanced weight gain, reduced feed conversion ratio, increased protein and feed efficiency ratios. Moreover, the immunocompetence of $O$. niloticus is also improved as evidenced by the hematological profile. These results indicate that diets enriched with plant extracts have beneficial effects on fish health and enhance the immune system and hence they could play an important role in preventing disease outbreaks in aquaculture systems, thereby improving growth performance.

\section{Compliance with Ethical Standard}

Conflict of interests: The authors declare that for this article they have no actual, potential or perceived conflict of interests.

Ethics committee approval: Experimental design and fish handling of the current study had been approved by the Research Ethics Committee of Partido State University, Goa, Camarines Sur, Philippines.

Funding disclosure: The research work was supported by the University Research and Exploration Fund of Partido State University, Goa, Camarines Sur dated September 16, 2020.
Acknowledgments: The authors thank the Campus Dean of Partido State University Sagnay Campus for providing necessary infrastructure facility to carry out the work. The technical assistance of Mr. Jericho Encinas is likewise acknowledged.

Disclosure: -

\section{References}

Abd El-Hakim, N.F., Ahmad, M.H., Azab, E.S., Lashien, M.S., Baghdady, E.S., (2010). Response of Nile tilapia, Oreochromis niloticus to diets supplemented with different levels of fennel seeds meal (Foeniculum vulgare). Abbassa-International Journal for Aquaculture, 3, 215-230.

Abonyi, F.O., Iyi, E.O., Machebe, N.S. (2012). Effects of feeding sweet potato (Ipomoea batatas) leaves on growth performance and nutrient digestibility of rabbits. African Journal of Biotechnology, 11(15), 3709-3712.

https://doi.org/10.5897/AJB11.3103

Adewolu, M.A., (2008). Potentials of Sweet potato Ipomoea batatas leaf meal as dietary ingredient for Tilapia zilli fingerlings. Pakistan Journal of Nutrition, 7(3), 444-449.

https://doi.org/10.3923/pjn.2008.444.449

Afuang W., Siddhuraju P., Becker K. (2003). Comparative nutritional evaluation of raw, methanol extracted residues and methanol extracts of moringa (Moringa oleifera Lam.) leaves on Oreochromis niloticus. Aquaculture Research, 34, 11471159.

https://doi.org/10.1046/j.1365-2109.2003.00920.x

Ajeel, S.G. and Al-Faragi, J.K. (2013). Effect of ginger, Zingiber officinale and garlic, Allium sativum to enhance health of common carp, Cyprinus carpio. The Iraqi Journal of Veterinary Medicine, 37, 59-62.

https://doi.org/10.30539/iraqijvm.v37i1.332

An, L.V., (2004). Sweet potato leaves for growing pigs. Biomass yield, digestion and nutritive value. Doctor's thesis, Swedish University of Agriculture Sciences, pp: 49.

Baleta, F.N., Lin, Y-C., Chen, Y-Y., Chen, J-C. Yeh, S-T. Putra, D.F., Huang, C-L. (2013). Efficacy of Sargassum oligocystum Extract on the Innate Immunity of White Shrimp Li- 
topenaeus vannamei and its resistance against Vibrio alginolyticus. Journal of the Fisheries Society of Taiwan, 40(4), 241256.

Bedford, M. (2000). Removal of antibiotic growth promoters from poultry diets: implications and strategies to minimize subsequent problems. Worlds Poultry Science Journal, 56, 347365 .

https://doi.org/10.1079/WPS20000024

Citarasu, T. (2010). Herbal biomedicines: a new opportunity for aquaculture industry. Aquaculture International, 18, 403414.

https://doi.org/10.1007/s10499-009-9253-7

Chakraborty, S.B., Hancz, C., (2011). Application of phytochemicals as immunostimulant, antipathogenic and antistress agents in finfish culture. Reviews in Aquaculture 3, 103-119. https://doi.org/10.1111/j.1753-5131.2011.01048.x

De Silva, S., Anderson, T. (1995). Fish Nutrition in Aquaculture, first ed., Chapman and Hall, London.

Dügenci, S.K., Arda, N., Candan, A. (2003). Some medicinal plants as immunostimulant for fish. Journal of Ethnopharmacology, 88, 99-106.

https://doi.org/10.1016/S0378-8741(03)00182-X

Ekenyem, B.U., Madubuike, F.N. (2006). An assessment of Ipomoea asarifiolia leaf meal as feed ingredient in broiler chick production. Pakistan Journal of Nutrition, 5, 46-50.

https://doi.org/10.3923/pjn.2006.46.50

Fazio, F., Marafioti, S., Torre, A., Sanfilippo, M., Panzera, M., Faggio, C. (2013). Haematological and serum protein profiles of Mugil cephalus: effect of two different habitats. Ichthyological Research, 60(1), 36-42.

https://doi.org/10.1007/s10228-012-0303-1

Fujiki, K., Matsuyama, H., Yano, T. (1992). Effect of hotwater extracts from marine algae on resistance of carp and yellowtail against bacterial infections. Science Bulletin, Faculty of Agriculture. Kyushu University, 47, 137-141.
Galina, J., Yin, G., Ardó, L., Jeney, Z. (2009). The use of immunostimulating herbs in fish. An overview of research. Fish Physiology and Biochemistry, 35, 669-676.

https://doi.org/10.1007/s10695-009-9304-z

Ganzon-Naret, E.S. (2014). Utilization of Moringa oleifera leaf meals as plant protein sources at different inclusion levels in fish meal based diets fed to Lates calcarifer, ABAH Bioflux 6(2), 158-167.

Garg, C.K., Sahu, N.P, Shamna, N, Deo, A.D., Kumar, S., Maiti, M.K. (2019). Effect of dietary Houttuynia cordata leaf meal and leaf extract on the growth performance, nutrient utilization and expression of IGF-I gene in Labeo rohita. Aquaculture Nutrition, 1110.

https://doi.org/10.1111/anu.12891

Haghighi, M., Rohani, M.S. (2013). The effects of powdered ginger, Zingiber officinale on the haematological and immunological parameters of rainbow trout Oncorhynchus mykiss. Journal of Medicinal Plant and Herbal Therapy Research, 1, 8-12.

Harikrishnan, R., Balasundaram, C., Heo, M.S. (2012). Effect of Inonotus obliquus enriched diet on hematology, immune response, and disease protection in kelp grouper, Epinephelus bruneus against Vibrio harveyi. Aquaculture, 344-349, 48-53. https://doi.org/10.1016/j.aquaculture.2012.03.010

Hevrøy, E., Espe, M., Waagbø, R., Sandnes, K., Ruud, M., Hemre, G.I. (2005). Nutrient utilization in Atlantic salmon (Salmo salar L.) fed increased levels of fish protein hydrolysate during a period of fast growth. Aquaculture Nutrition, 11, 301313.

https://doi.org/10.1111/j.1365-2095.2005.00357.x

Hong, N.T.T., Wanapat, M., Wachirapakorn, C.K.P., Rowlinson, P. (2003). Effect of timing of initial cutting and subsequent cutting on yields and chemical compositions of cassava hay and its supplementation on lactating dairy cows. Asian- Australian Journal of Animal Science, 16, 1763-1769. https://doi.org/10.5713/ajas.2003.1763 
Hou, W.Y., Chen, J.C., (2005). The immunostimulatory effect of the hot-water extract of G. tenuistipitata on the white shrimp $L$. vannamei and its resistance against $V$. alginolyticus. Fish and Shellfish Immunology, 19, 127-138.

https://doi.org/10.1016/j.fsi.2004.11.009

Ishida, H., H. Suzuno, N. Sugiyama, S. Imami, T. Tadokoro and A. Meakawa, (2000). Nutritive value on chemical components of leaves, stalks and stem of sweet potato (Ipomoea batatas Poir). Food Chemistry, 68, 359-367.

https://doi.org/10.1016/S0308-8146(99)00206-X

Jafarian, H., T.G. Azari, A.A. Kamali, M. Soltani, R.M. Habibi, (2007). The use of probiotic Bacillus bioencapsulated with Artemia urmiana nauplii for the growth and survival in Acipenser persicus larvae. Agriculture Science and Natural Resources, 14, 77-87.

Jain, M., Ganju, L., Katiyal, A., Padwad, Y., Mishra, K.P., Chanda, S. (2008). Effect of Hippophae rhamnoides leaf extract against Dengue virus infection in human blood-derived macrophages. Phytomedication, 15, 793-799.

https://doi.org/10.1016/j.phymed.2008.04.017

Kaleeswaran, B., Ilavenil, S., Ravikumar, S., (2011). Growth response, feed conversion ratio and antiprotease activity of Cynodon dactylon (L.) mixed diet in Catla catla. Journal of Animal and Veterinary Advances, 10, 511-517.

https://doi.org/10.3923/javaa.2011.511.517

Labh, S.N., Shakya, S.R., Gupta, S.K., Kumar, N., Kayastha, B.L. (2017). Effects of lapsi fruits (Choerospondias axillaris Roxburgh, 1832) on immunity and survival of juvenile tilapia (Oreochromis niloticus Linnaeus, 1758) infected with Aeromonas hydrophila. International Journal of Fauna and Biological Studies, 5, 571-577.

Li, P., Lewis, D.H., Galtin, D.M. (2004). Dietary oligonucleotides from yeast RNA influence immune responses and resistance of hybrid striped bass (Morone chrysops x Morone saxatilis) to Streptococcus iniae infection. Fish and Shellfish Immunology, 16, 561-569.

https://doi.org/10.1016/j.fsi.2003.09.005
Noori, A., Nasir, Amar, Y., Jassim, A. (2013). Effect of different dietary proteins and fats on some biochemical blood parametrs in common carp fingerlings (Cyprinus carpio) reared in floating cages. Asian Journal of Experimental Biological Sciences, 4, 293-298.

Nya, E., Austin, B. (2009). Use of dietary ginger, Zingiber officinale Roscoe, as an immunostimulant to control Aeromonas hydrophila infections in rainbow trout, Oncorhynchus mykiss. Journal of Fish Diseases, 32, 971-977. https://doi.org/10.1111/j.1365-2761.2009.01101.x

Olmedo Sanchez, J.A., Curiel Flores, A., Orozco, J.R. (2009). The effect of a herbal growth promoter feed additive on shrimp performance. Research Journal of Biological Sciences, 4, 1022-1024.

Pavaraj, M., Balasubramanian, V., Baskaran, S., Ramasamy, P. (2011). Development of immunity by extract of medicinal plant Ocimum sanctum on common carp Cyprinus carpio (L.). Research Journal of Immunology, 4, 12-18.

https://doi.org/10.3923/rij.2011.12.18

Pratheepa, V., Sukumaran, N. (2014). Effect of Euphorbia hirta plant leaf extract on immunostimulant response of Aeromonas hydrophila infected Cyprinus carpio. Peer Journal 2, e671.

https://doi.org/10.7717/peerj.671

Punitha, S.M.J., Babu, M.M., Sivaram, V., Shankar, V.S., Dhas, S.A., Mahesh, T.C., Immanuel, G., Citarasu, T., (2008). Immunostimulating influence of herbal biomedicines on non- specific immunity in Grouper Epinephelus tauvina juvenile against Vibrio harveyi in- fection. Aquaculture International 16, 511-523.

https://doi.org/10.1007/s10499-007-9162-6

Putra, A., Santoso, U., Lee, M.-C., Nan, F.-H. (2013). Effects of dietary katuk leaf extract on growth performance, feeding behavior and water quality of grouper Epinephelus coioides. Aceh International Journal of Science and Technology, 2, 1725. 
Raa, J., Rorstad, G., Engstad, R.E., Robertson, B. (1992). The use of immunostimulants to increase resistance of aquatic organisms to microbial infections. In: Shariff, M., Subasinghe, R.P., Arthur, J.R. (Eds.), Disease in Asian Aquaculture. Proceedings of the First Symposium on Diseases in Asian Aquaculture. Asian Fisheries Society, Philippines, pp. 39-50. 1.

Reverter, M., Bontemps, N., Lecchini, D., Banaigs, B., Sasal P. (2014). Use of plant extracts in fish aquaculture as an alternative to chemotherapy: current status and future perspectives. Aquaculture, 433, 50-61.

https://doi.org/10.1016/j.aquaculture.2014.05.048

Robertsen, B. (1999). Modulation of the non-specific defence of fish by structurally conserved microbial polymers. Fish and Shellfish Immunology, 9, 269-290.

https://doi.org/10.1006/fsim.1998.0186

Shalaby, A.M., Khattab, Y.A., Abdel Rahman, A.M. (2006). Effects of garlic (Allium sativum) and chloramphenicol on growth performance, physiological parameters and survival of Nile tilapia (Oreochromis niloticus). Journal of Venomous Animal Toxins 12, 172-201.

https://doi.org/10.1590/S1678-91992006000200003

Sheikhlar, A., Alimon, A.R., Daud, H., Saad, C.R., Webster, C.D., Meng, G.Y. (2014). White mulberry (Morus alba) foliage methanolic extract can alleviate Aero- monas hydrophila infection in African Catfish (Clarias gariepinus). The Scientific World Journal, 2014, 592709.

https://doi.org/10.1155/2014/592709

Takaoka, O., Ji, S.-C., Ishimaru, K., Lee, S.-W., Jeong, G.S., Ito, J., Biswas, A., Takii, K. (2011). Effect of rotifer enrichment with herbal extracts on growth and resistance of red sea bream, Pagrus major (Temminck and Schlegel) larvae against Vibrio anguillarum: effect of medicinal herb on larval red sea bream. Aquaculture Research, 42, 1824-1829.

https://doi.org/10.1111/j.1365-2109.2010.02783.x
Talpur, A.D., Ikhwanuddin, M. (2013). Azadirachta indica (neem) leaf dietary effects on the immunity response and disease resistance of Asian seabass, Lates calcarifer challenged with Vibrio harveyi. Fish and Shellfish Immunology, 34, 254264.

https://doi.org/10.1016/j.fsi.2012.11.003

Talpur, A.D., Ikhwanuddin, M., Bolong, A-M.A. (2013). Nutritional effects of ginger, Zingiber officinale Roscoe on immune response of Asian sea bass, Lates calcarifer and disease resistance against Vibrio harveyi. Aquaculture, 400, 46-52.

https://doi.org/10.1016/j.aquaculture.2013.02.043

Tewary, A., Patra, B. (2011). Oral administration of baker's yeast (Saccharomyces cer-evisiae) acts as a growth promoter and immunomodulator in Labeo rohita (Ham.). Journal of Aquaculture Research and Development, 2, 1-7.

https://doi.org/10.4172/2155-9546.1000109

Vaseeharan, B., Thaya, R., (2013). Medicinal plant derivatives as immunostimulants: an al- ternative to chemotherapeutics and antibiotics in aquaculture. Aquaculture International, 22, 1079-1091.

https://doi.org/10.1007/s10499-013-9729-3

Wu, Y.S., Chen, Y.Y., Ueng, P.S., Nan, F.H. (2016). Effects of medicinal herbs Plantago asiatica, Houttuynia cordata and Mentha haplocalyx on non-specific immune responses of cobia (Rachycentron canadum). Fish and Shellfish Immunology, 58, 406-414.

https://doi.org/10.1016/j.fsi.2016.09.043

Zhou, J., Huang, J., Song, X.L. (2003). Applications of immunostimulants in aquaculture. Marine Fisheries Research, 24, 70-79. 